\title{
Esophageal granular cell tumor successfully resected by endoscopic submucosal dissection
}

\author{
Masanobu Nakajima $\cdot$ Hiroyuki Kato $\cdot$ Hiroto Muroi $\cdot$ Akira Sugawara $\cdot$ \\ Miyako Tsumuraya $\cdot$ Kichiro Otsuka $\cdot$ Yasushi Domeki $\cdot$ Shinichi Onodera $\cdot$ \\ Kinro Sasaki - Masahiro Tsubaki - Makoto Sohda - Tatsuya Miyazaki • \\ Hiroyuki Kuwano
}

Received: 22 March 2011/ Accepted: 28 June 2011/Published online: 14 July 2011

(C) The Author(s) 2011. This article is published with open access at Springerlink.com

\begin{abstract}
Granular cell tumors of the esophagus are rare neoplasms and their diagnosis is mainly based on histopathologic examination of endoscopic biopsies. With the development of endoscopic techniques, there has been a marked increase in local treatment modalities for early esophageal neoplasms. In this case report, we describe the removal of a granular cell tumor by the endoscopic submucosal dissection technique, and briefly discuss the literature on clinicopathologic aspects and management of granular cell tumors.
\end{abstract}

Keywords Biopsy · Esophageal neoplasms .

Granular cell tumor $\cdot$ Surgical endoscopy

\section{Introduction}

Granular cell tumors (GCT) are relatively infrequent lesions that were initially described by Abrikossoff [1] as part of a series of 5 tumors of the tongue, which he termed myoblastoma. In 1931, he described the first case of this kind of neoplasm located in the esophagus [2] and since

M. Nakajima $(\bowtie) \cdot$ H. Kato · H. Muroi · A. Sugawara •

M. Tsumuraya · K. Otsuka · Y. Domeki - S. Onodera ·

K. Sasaki · M. Tsubaki

Department of Surgery I, Dokkyo Medical University,

880 Kitakobayashi, Mibu, Shimotsuga-gun,

Tochigi 321-0293, Japan

e-mail: mnakajim@dokkyomed.ac.jp

M. Sohda $\cdot$ T. Miyazaki $\cdot$ H. Kuwano

Department of General Surgical Science (Surgery I),

Gunma University, Graduate School of Medicine,

Maebashi 371-8511, Japan then approximately 200 cases of GCT have been documented [3].

In the esophagus, the lesion is generally restricted to the submucosal layer, although occasionally it can also affect the mucosal layers and muscularis propria of the organ. Histologically, different cell types, for example histiocytes, fibroblasts, or intestinal mesenchymal cells, have been reported to be the source of this tumor. However, the most widely accepted theory was that it was of myogenic origin, hence its former name of "granular cell myoblastoma". Since 1950 and with the introduction of histochemical techniques, it has clearly been shown that it is of neurogenic origin, arising from the Schwann cells [2] which, in the esophagus, form part of the submucosal neuronal plexus. There are many cases of endoscopic mucosal resection (EMR) as treatment for GCTs. However, to our knowledge, there are few reports of endoscopic submucosal dissection (ESD) [4]. This article reports a case of a GCT in the esophagus which was resected by ESD.

\section{Case report}

A 51-year-old man received an endoscopic examination after an esophageal lesion was found in an upper gastrointestinal (GI) X-ray series health examination. At the time of diagnosis he was completely asymptomatic and his blood tests were normal. Endoscopy identified an elevated yellow lesion, located $37 \mathrm{~cm}$ distal from the incisor teeth with a submucosal aspect and a depression in the center, measuring approximately $12 \mathrm{~mm}$, which was rounded and coated with normal mucosa. Iodine staining showed a minimally unstained top of the tumor (Fig. 1). Endoscopic ultrasonography (EUS) using a $20 \mathrm{MHz}$ catheter probe and the water filling method identified a submucosal tumor 

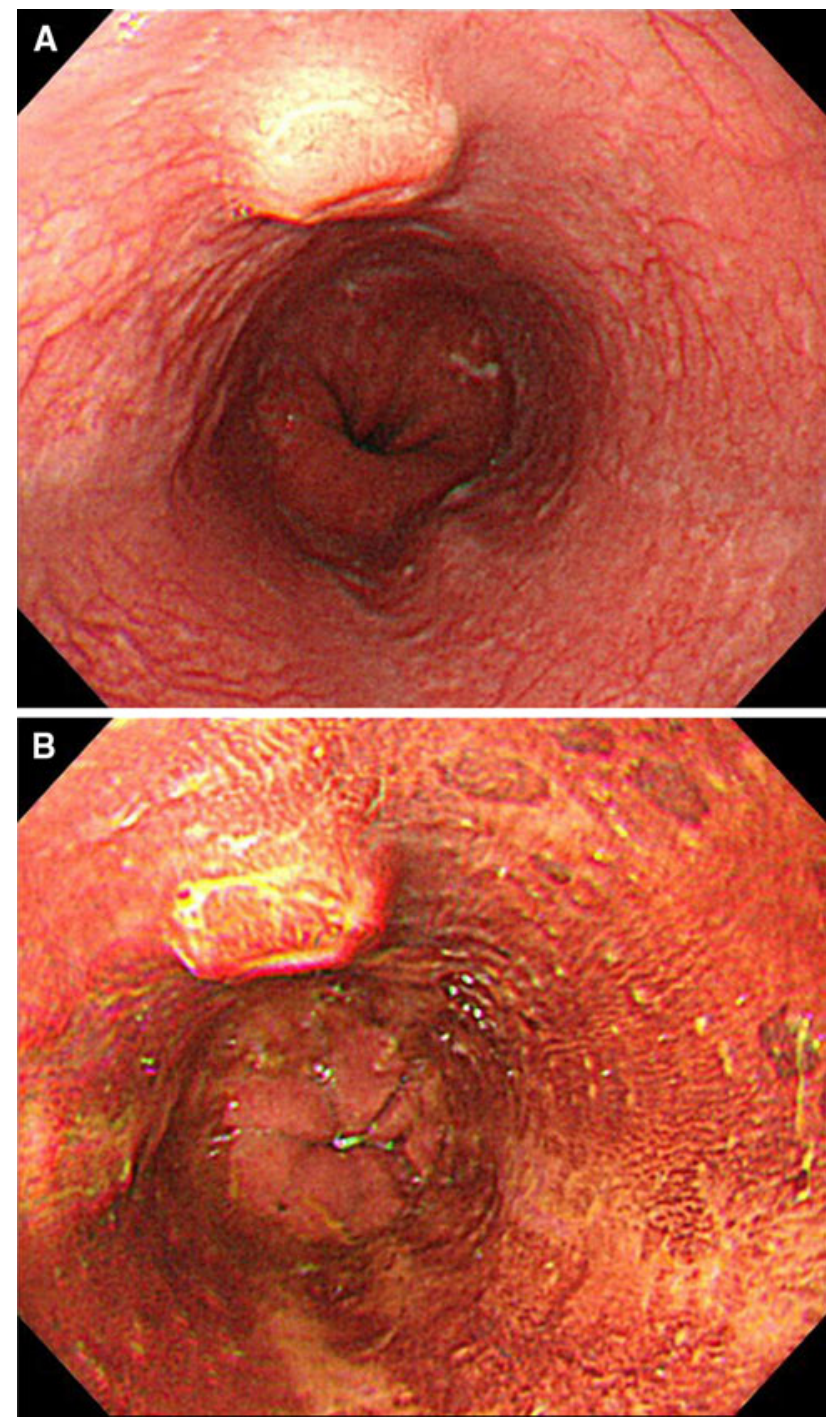

Fig. 1 Upper gastrointestinal endoscopy. a An elevated yellow lesion located $37 \mathrm{~cm}$ distal from the incisor teeth, with a submucosal aspect and a depression in the center, was identified. It was round and mostly coated with normal mucosa. b Lugol staining showed minimal unstained top of the tumor

with a diameter of $10 \mathrm{~mm}$. It was solid and the border was unclear but the bottom of the tumor was demarcated from the adjacent normal muscle layer, and was therefore confirmed to be located in the submucosal layer. The tumor was hypoechoic, but was hyperechoic compared with the adjacent muscle layer (Fig. 2). No mediastinal adenopathies were identified. Histological analysis of tissue obtained with standard endoscopic forceps revealed stroma infiltrated by cells with eosinophilic cytoplasm of granular aspect whose central nuclei showed no evidence of atypia or mitotic figures (Fig. 3). The squamous surface epithelium showed pseudoepitheliomatous hyperplasia. On the basis of these histopathological findings, the lesion was diagnosed as a GCT. An upper GI X-ray series showed an

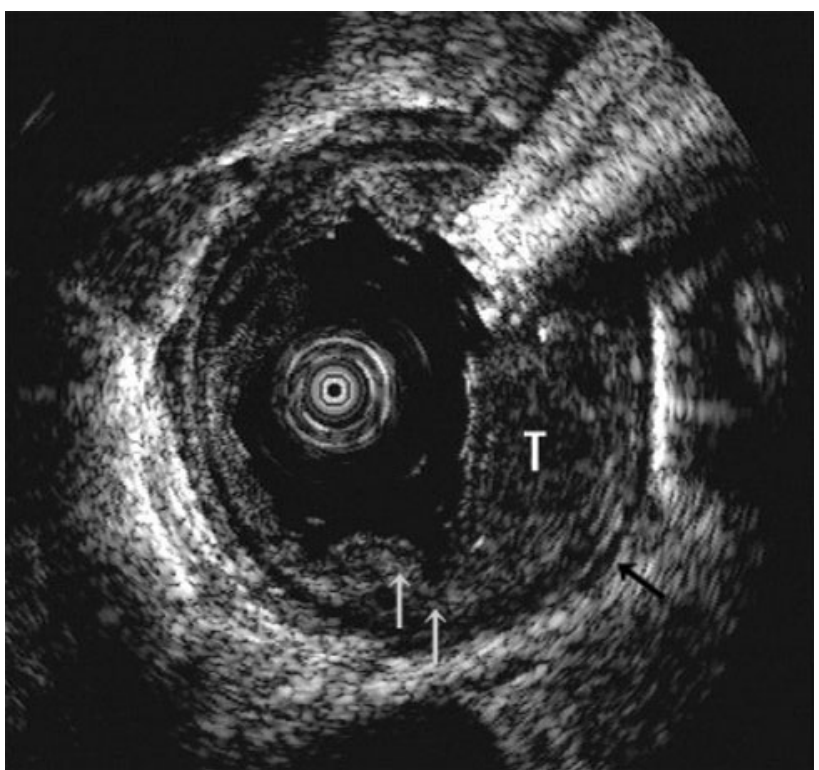

Fig. 2 Endoscopic ultrasonography showing a tumor which was solid, hypoechoic, with a diameter of $10 \mathrm{~mm}(\mathrm{~T})$. This tumor was located in the submucosal layer (white arrow) and demarcated from the muscle layer (black arrow)

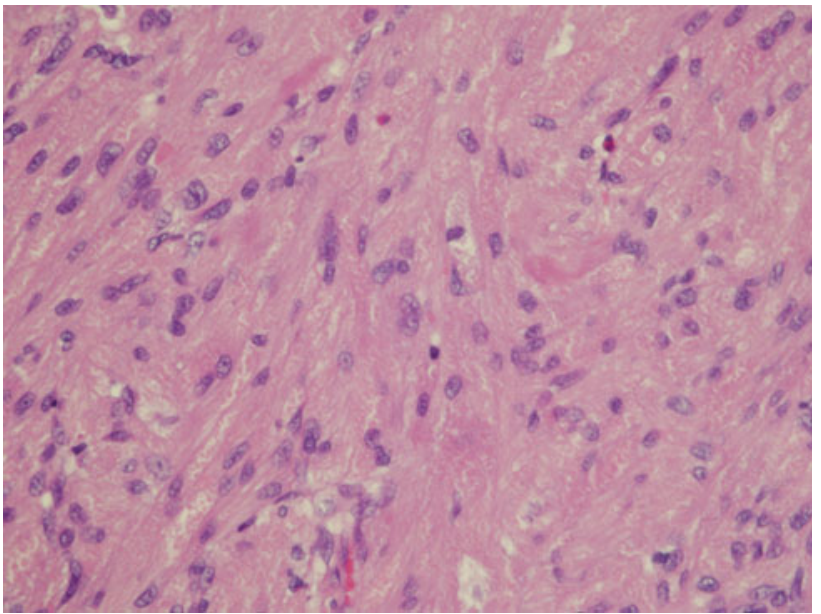

Fig. 3 The histological analysis revealed stroma infiltrated by cells with eosinophilic cytoplasm of granular appearance whose central nuclei showed no evidence of atypia or mitotic figures

elevated lesion with slight depression at the lower esophagus (Fig. 4). A computed tomography scan of the chest and abdomen revealed the solid mass in the distal esophagus but no additional pathology.

The patient subsequently underwent an ESD using sodium hyaluronate, a small-caliber tip transparent hood (ST hood; Fujifilm, Japan) and a water jet short needle knife (Flush knife; Fujifilm) according to the method developed by Toyonaga [5]. The ESD procedure was carried out using a single-channel upper GI endoscope (Olympus, Japan) and a high-frequency generator with an 


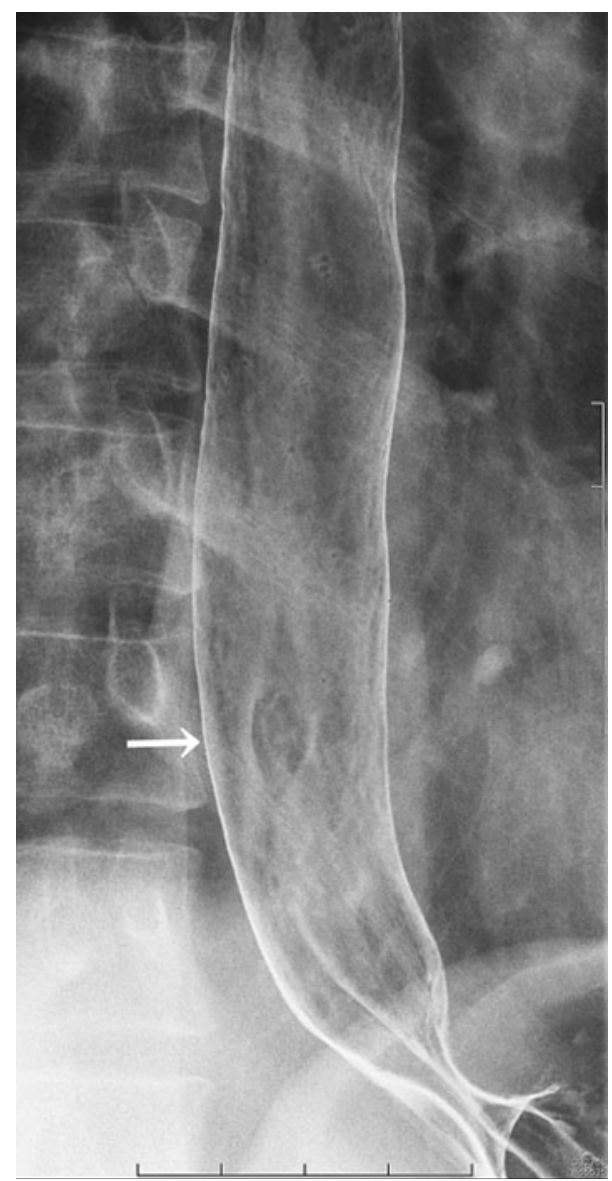

Fig. 4 An upper gastrointestinal X-ray series showed an elevated lesion with slight depression at the lower esophagus (arrow)

automatically controlled system (Endocut mode; ICC200; ERBE Elektromedizin, Germany). An ST hood was fitted on the tip of the endoscope to obtain a constant view and to create tension on the connective tissue for dissection. Lugol staining was performed to mark the margins of the lesion. With use of the Flush knife, dots were placed about $3 \mathrm{~mm}$ outside the margins at $2 \mathrm{~mm}$ intervals. Following an initial injection of $2 \mathrm{~mL}$ saline, a submucosal fluid cushion was created using a solution prepared with a mixture of hyaluronic acid, saline, indigo carmine, and epinephrine. Approximately $2 \mathrm{~mL}$ of the solution at a time was injected into the submucosal layer, and repeated until the mucosa was elevated. After lifting the lesion, the mucosa was gently cut with the Flush knife, using the Endocut mode. En-bloc resection with tumor-free lateral/basal margins was accomplished (Fig. 5). To control minor bleeding, hemostatic forceps were used in soft coagulation mode. The resected specimen contained a massive tumor of $11 \times 7 \mathrm{~mm}$, with eosinophilic cytoplasm with a granular appearance located from the lamina propria mucosae to the submucosal layer (Fig. 6). The patient was discharged after 1 week without any complications. This method enabled
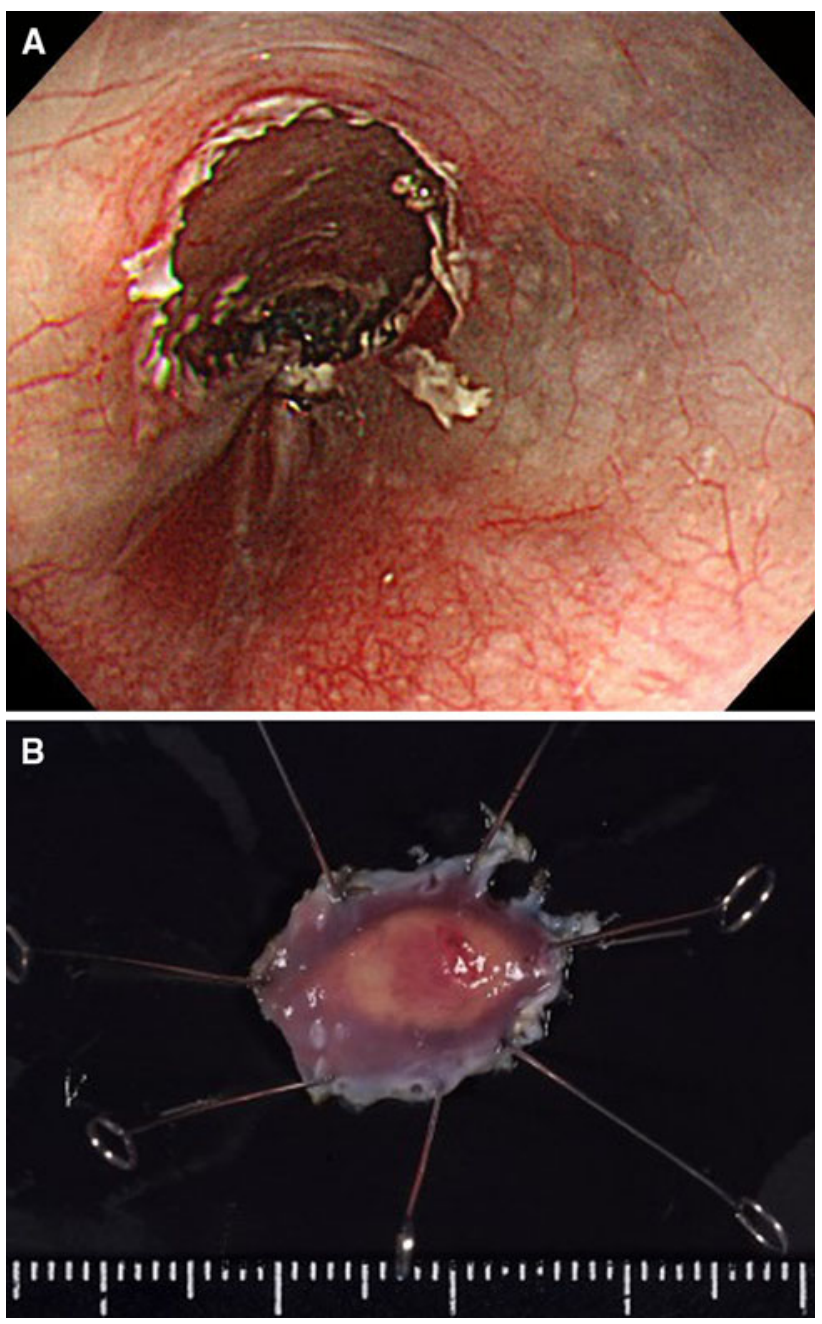

Fig. 5 Endoscopic submucosal dissection. a Lower esophagus where the tumor and mucosa were removed. b Macroscopically, the surgical margin of resected lesion was free from tumor cells

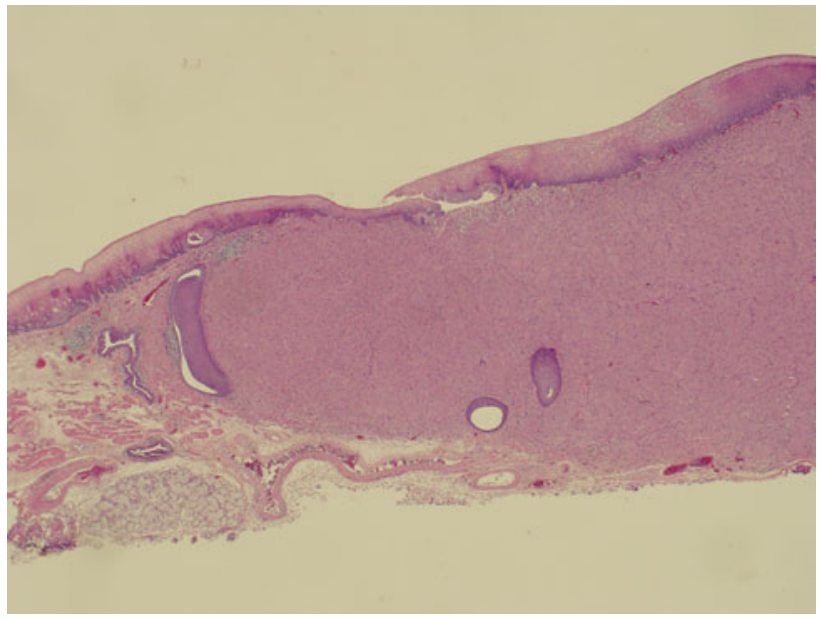

Fig. 6 The resected specimen contained an $11 \times 7 \mathrm{~mm}$ tumor with eosinophilic cytoplasm with a granular appearance located from just below the squamous epithelium to the lamina propria mucosae 
submucosal incision under direct visualization, and thus enabled precise determination of both the lateral and vertical margins to be resected. Microscopically, the surgical margin was free from tumor cells. Follow-up endoscopy 6 weeks after removal of tumor showed scar tissue from mucosal dissection; no masses or nodules were detected.

\section{Discussion}

Although GCTs are uncommon tumors in the GI tract, nearly one-third occur in the esophagus $[6,7]$, the most common site of origin of GI GCTs. Most esophageal GCTs are found incidentally during endoscopy of the upper GI performed for other reasons. Although a GCT is usually asymptomatic, when the tumor is larger than $1 \mathrm{~cm}$, it may cause dysphagia [3].

A GCT has a characteristic appearance on endoscopy. The tumor usually appears as a yellowish-white, firm, sessile submucosal mass. Differential diagnosis should include an esophageal cyst, epithelial lesions, for example glycogenic acanthosis, an inflammatory polyp, squamous papilloma, and other submucosal tumors, for example leiomyoma, lipoma, and hamartoma [4].

GCTs were originally considered to be of myogenic origin, but electron microscopic and immunohistochemical studies confirmed the Schwann-cell origin of the tumors. Histologically, these tumors consist of polygonal and fusiform cells in compact "nests" [8]. Cells have small dark nuclei and abundant, fine, granular eosinophilic acidSchiff-positive, diastase-resistant cytoplasm [9]. GCTs of the skin, larynx, and esophagus are known to induce pseudoepitheliomatous hyperplasia in the malpighian epithelium. This feature may simulate a primary squamous cell carcinoma [7, 10].

Although the natural history of the tumor is unclear, most esophageal GCTs have a benign clinical course. However, approximately $1.5-2.7 \%$ of all cases reported in the literature were regarded as malignant variants. The infiltrative growth pattern and the presence of metastases are important features in differentiating between malignant and benign tumors because they may be of very similar appearance histologically. Malignant lesions are usually larger than $4 \mathrm{~cm}$, with evidence of rapid recent growth, tend to recur locally after resection, and may have subtle histologic features, for example nuclear pleomorphism, increased nuclear size, tumor cell necrosis, large nucleoli, mitotic figures ( 2 or more/10 high power fields), and tumor cell spindling [11].

The optimum treatment for GCTs remains controversial, but the current treatment options are a conservative approach with regular endoscopic follow-up for tumors
$<10 \mathrm{~mm}$ in diameter without evidence of malignant change [12], and surgical excision for tumors $>20 \mathrm{~mm}$ in diameter, benign GCTs causing symptoms, or when malignancy is suspected [13]. If no malignant changes are detected in the removed specimen, additional treatment or follow-up is not considered necessary [3]. EMR was recently reported to be an effective treatment, and EUS is thought to be most useful for deciding if a tumor meets the criteria for endoscopic removal, including small size $(<20 \mathrm{~mm})$ and non-attachment to the muscle layer $[14,15]$. In a series of 650 esophageal mucosal cancers removed with EMR, Makuuchi [16] reported an incidence of complications of $4.8 \%$ (perforation $0.7 \%$, bleeding $3.1 \%$, stricture $1.6 \%$ ).

ESD for esophageal pathology has recently been established, and the affected mucosa is incised and removed using a variety of endoscopic electrosurgical knives. Using ESD, a wider range of the mucosa can be resected in one piece more reliably using an endoscope. Takahashi et al. [17] reported that the incidence of complications was not significantly different between ESD and EMR-perforation $2.6 \%$, mediastinal emphysema $4.3 \%$, pneumonia $2.6 \%$, and stenosis $17.2 \%$. In our case, after submucosal injection of sodium hyaluronate to maintain sufficient thickening of the submucosal tissue, dissection of the mucosa and submucosa with a Flush knife was performed by the method developed by Toyonaga [5]. We preferred ESD for its more accurate resection than conventional EMR, and sodium hyaluronate solution for its ability to maintain submucosal elevation for a longer time [18]. Additional esophagectomy with lymph node dissection was not required, because no submucosal invasion or vessel permeation was seen in the endoscopically resected specimen.

Endoscopic resection is less invasive and, for smaller tumors, results in fewer complications than esophagectomy; on the other hand there is a case report of EMR of a malignant GCT with a diameter of $10 \mathrm{~mm}$ [17]. With regard to GCTs from 10 to $20 \mathrm{~mm}$ in diameter, we believe endoscopic resection (EMR or ESD) may be preferable, as described elsewhere $[19,20]$.

Concerning esophageal GCTs exceeding $20 \mathrm{~mm}$, esophagectomy had been performed until quite recently. However, esophagectomy is the therapeutic option with the highest mortality [21]. Because ESD has been established as safer and less invasive therapy, it is expected to be the best therapeutic option for mucosal or submucosal esophageal GCTs exceeding $20 \mathrm{~mm}$.

In summary, GCTs of the esophagus are rare neoplasms. Endoscopic biopsies are the mainstay of diagnosis. Endoscopic and endosonographic evaluation of the lesion defines the location and extent of the tumor and its suitability for endoscopic treatment. ESD is a safe and accurate procedure for identified cases. 
Open Access This article is distributed under the terms of the Creative Commons Attribution Noncommercial License which permits any noncommercial use, distribution, and reproduction in any medium, provided the original author(s) and source are credited.

\section{References}

1. Abrikossoff AI. Uber Myome, augehend von der quergestreiften willkurlichen Muskulatur. Virchows Arch Pathol Anat. 1926;260: 214-33.

2. Abrikossoff AI. Weitere untersuchungen über myoblasten myome. Virchows Arch Pathol Anat. 1931;280:723-40.

3. Goldblum JR, Rice TW, Zuccaro G, Richter JE. Granular cell tumors of the esophagus: a clinical and pathologic study of 13 cases. Ann Thorac Surg. 1996;62:860-5.

4. Hülagü S, Sentürk O, Aygün C, Gürbüz Y, Kocaman O, Celebi A, et al. Granular cell tumor of esophagus removed with endoscopic submucosal dissection. Turk J Gastroenterol. 2007;18: 188-91.

5. Toyanaga T, Man-I M, Ivanov D, Sanuki T, Morita Y, Kutsumi $\mathrm{H}$, et al. The results and limitations of endoscopic submucosal dissection for colorectal tumors. Acta Chir Iugosl. 2008;55: $17-23$.

6. Lack EE, Worsham GF, Callihan MD, Crawford BE, Klappenbach S, Rowden G, et al. Granular cell tumors: a clinicopathologic study of 110 cases. J Surg Oncol. 1980;13:301-6.

7. Johnston MJ, Helwig EB. Granular cell tumors of the gastrointestinal tract and perianal region: a study of 74 cases. Dig Dis Sci. 1981;26:807-16.

8. Giacobbe A, Facciorusso D, Conoscitore P, Spirito F, Squillante MM, Bisceglia M. Granular cell tumor of the esophagus. Am J Gastroenterol. 1988;83:1398-400.

9. Cohle SD, McKechnie JC, Truong L, Jurco S 3rd. Granular cell tumor of the esophagus. Report of three cases. Am J Gastroenterol. 1981;75:431-5.

10. Gibbons JR, Bharucha H, Soorae AS. Granular cell tumor of the esophagus. Am J Gastroenterol. 1980;74:161-4.

11. Fanburg-Smith JC, Meis-Kindblom JM, Fante R, Kindblom LG. Malignant granular cell tumor of soft tissue: diagnostic criteria and clinicopathologic correlation. Am J Surg Pathol. 1998;22: 779-94.

12. Voskuil JH, van Dijk MM, Wagenaar SS, van Vliet AC, Timmer $\mathrm{R}$, van Hees PA. Occurrence of esophageal granular cell tumors in The Netherlands between 1988 and 1994. Dig Dis Sci. 2001;46:1610-4.

13. Coutinho DS, Soga J, Yoshikawa T, Miyashita K, Tanaka O, Sasaki K, et al. Granular cell tumors of the esophagus: a report of two cases and review of the literature. Am J Gastroenterol. 1985;80:758-62.

14. Saito K, Kato H, Fukai Y, Kimura H, Miyazaki T, Kashiwabara $\mathrm{K}$, et al. Esophageal granular cell tumor covered by intramucosal squamous cell carcinoma: report of a case. Surg Today. 2008;38: $651-5$.

15. Kim DU, Kim GH, Ryu DY, Lee DG, Cheong JH, Lee BE, et al. Endosonographic features of esophageal granular cell tumors using a high-frequency catheter probe. Scand J Gastroenterol. 2011;46:142-7.

16. Makuuchi H. Endoscopic mucosal resection for mucosal cancer in the esophagus. Gastrointest Endosc Clin North Am. 2001;11: 445-58.

17. Takahashi H, Arimura Y, Masao H, Okahara S, Tanuma T, Kodaira J, Kagaya H, Shimizu Y, Hokari K, Tsukagoshi H, Shinomura Y, Fujita M. Endoscopic submucosal dissection is superior to conventional endoscopic resection as a curative treatment for early squamous cell carcinoma of the esophagus (with video). Gastrointest Endosc. 2010;72:255-64, 264.e1-2.

18. Yamamoto H, Kawata H, Sunada K, Sasaki A, Nakazawa K, Miyata T, et al. Successful en bloc resection of large superficial tumors in the stomach and colon using sodium hyaluronate and small-caliber-tip transparent hood. Endoscopy. 2003;35:690-4.

19. Okahara S, Tanaka S, Haruma K. A case of granular cell tumor of the esophagus resected endoscopically. J Hiroshima Med Assoc. 1995;48:810-4.

20. Yasuda I, Tomita E, Nagura K, Nishigaki Y, Yamada O, Kachi H. Endoscopic removal of granular cell tumors. Gastrointest Endosc. 1995;41:163-6.

21. De Rezende L, Lucendo AJ, Alvarez-Argüelles H. Granular cell tumors of the esophagus: report of five cases and review of diagnostic and therapeutic techniques. Dis Esophagus. 2007;20: 436-43. 